\title{
Pengaruh Distres Emosional terhadap Perilaku Merokok Remaja di Indonesia (Analisis Data Riskesdas 2013)
}

\author{
Diah Adni Fauziah ${ }^{1}$, Sudarto Ronoatmodjo ${ }^{2}$, Pandu Riono ${ }^{3}$ \\ ${ }^{1}$ STIKES Wijaya Husada, Program Studi Kesehatan Masyarakat, Bogor \\ ${ }^{2}$ Departemen Epidemiologi, Fakultas Kesehatan Masyarakat Universitas Indonesia, Depok \\ ${ }^{3}$ Departemen Biostatistik, Fakultas Kesehatan Masyarakat Universitas Indonesia, Depok
}

\begin{abstract}
Abstrak
Latar Belakang: Prevalensi merokok pada remaja lebih tinggi dibandingkan kelompok dewasa. Salah satu yang menyebabkan perilaku merokok remaja adalah masa transisi menjadi dewasa yang psikologisnya cenderung tidak stabil. Hasil Global Youth Tobacco Survey tahun 2014 melaporkan konsumsi tembakau pada remaja sebesar 20,3\%, yaitu 19,4\% perokok saat ini dan 2,1\% bukan perokok. Distres emosional pada remaja dilaporkan memiliki hubungan terhadap perilaku merokok. Penelitian ini mempelajari besar efek distres emosional terhadap perilaku merokok remaja di Indonesia.

Metode: Data survei Riskesdas 2013 dianalisis dengan menggunakan regresi logistik berganda dengan mempertimbangkan desain survei. Variabel confounding yaitu umur, jenis kelamin, tempat tinggal, pendidikan kepala rumah tangga, sosial ekonomi keluarga, dan anggota rumah tangga yang merokok.

Hasil Hasil penelitian menunjukkan bahwa odds remaja yang merokok mengalami distres emosional sebesar 1,82 kali dibandingkan dengan remaja yang tidak merokok setelah dikontrol oleh variabel umur, pendidikan kepala rumah tangga, tempat tinggal, dan sosial ekonomi $(O R=1,82 ; 95 \%$ CI 1,66- 1,99).

Kesimpulan: Odds remaja yang merokok mengalami distres emosional sebesar 1,82 kali dibandingkan dengan remaja yang tidak merokok setelah dikontrol oleh variabel umur, pendidikan kepala rumah tangga, tempat tinggal, dan sosial ekonomi
\end{abstract}

Kata kunci: perilaku merokok, distres, remaja

\section{Emotional Distress Effect to Adolescent's Smoking Behavior in Indonesia (National Health Research 2013)}

\begin{abstract}
Background Smoking prevalence in adolescent is higher than adult. One of caused is transition fase among adolescent in unstabil psychology. In 2014, Global Youth Tobacco Survey reported the current use of any tobacco product by youth was $20,3 \%$, of which $19,4 \%$ were current tobacco smokers and $2,1 \%$ were current smokeless tobacco users. Emotional distress in adolescent associated with smoking behaviour. The aimed was to study emotional distress effect to smoking behavior among adolescent in Indonesia.

Method National Health Research Data Survey in 2013 was analyzed by using multiple logistic regression.

Result Result showed that odds adolescent smoker had to emotional distress 1,82 than adolescent nonsmoker adjusted by age, household education, addressed and family's socio economic. (OR=1,82; 95\% CI 1,66-1,99).

Conclusion Odds Adolescent smoker had to emotional distress 1,82 than adolescent nonsmoker adjusted by age, household education, addressed and family's socio economic.
\end{abstract}

Keywords: Smoking, Behaviour, Distress, Adolescent

Alamat Korespondensi:

Diah A. Fauziah

Program Studi Kesehatan Masyarakat,

STIKES Wijaya Husada, Bogor

Email: diahadniskm@gmail.com 


\section{PENDAHULUAN}

Penggunaan tembakau adalah penyebab utama kematian di dunia. ${ }^{1}$ Sekitar 5,4 juta kematian saat ini disebabkan oleh perilaku merokok. World Health Organization (WHO) menjelaskan bahwa lebih dari $80 \%$ penggunaan tembakau berhubungan dengan kematian di negara dengan pendapatan rendah hingga menengah pada tahun $2030 .{ }^{2}$ Penyakit akibat rokok dialami oleh para perokok dan orang yang terpapar asap rokok.

Rokok merupakan masalah kesehatan yang penting di Indonesia sejak Indonesia menduduki peringkat kelima konsumsi rokok di dunia. ${ }^{2}$ Data Survei Kesehatan Nasional tahun 2004, menunjukkan bahwa 34,5\% penduduk Indonesia adalah perokok yaitu sekitar 60 juta penduduk Indonesia. Hasil Global Youth Tobacco Survey tahun 2014 melaporkan konsumsi tembakau pada remaja sebesar $20,3 \%$, yaitu $19,4 \%$ perokok saat ini dan $2,1 \%$ bukan perokok. ${ }^{3}$ Prevalensi merokok lebih tinggi pada laki-laki dan sangat rendah pada perempuan. Diantara current smoker remaja, 75,9\% remaja berusaha untuk berhenti merokok. Kecenderungan berhenti merokok bertolak belakang dengan jumlah perokok remaja yang dari tahun ke tahun cenderung mengalami peningkatan karena $80 \%$ perokok remaja usia 13-15 tahun tidak berhasil saat mencoba berhenti merokok. ${ }^{4}$

Faktor yang mempengaruhi inisiasi merokok pada remaja yaitu faktor demografi, kondisi orangtua, pendidikan dan status sosial ekonomi. Faktor sosial juga memainkan peran penting. Faktor norma sosial misalnya pengaruh teman sebaya, kondisi keluarga, dan self-esteem ${ }^{5}$. Merokok juga berhubungan dengan distres psikiatri (atau gejala dari kecemasan dan depresi) pada kelompok remaja dan dewasa. Perilaku ini biasanya bermula dari masa remaja dan berlanjut pada masa dewasa ${ }^{6}$. Prevalensi distres emosional pada remaja berusia 15-24 tahun menurut data Riskesdas 2007 yaitu $8,7 \%$. Hasil penelitian sebelumnya mengatakan bahwa faktor emosional dan perilaku berhubungan dengan perilaku merokok ${ }^{7}$. Remaja sebagai kelompok yang paling banyak menerima awal tekanan berupa kecemasan di jenjang pendidikannya, sementara mereka sebelumnya belum pernah mengalami atau mengatasi stress yang dapat mengakibatkan tingginya gejala psikiatri dan mulai merokok. ${ }^{8}$ Hubungan distres emosional dengan perilaku merokok akan menjadi kompleks karena ada beberapa faktor yang mempengaruhinya. Oleh karena itu, mempelajari seberapa besar efek distres emosional dengan perilaku merokok pada remaja adalah hal yang penting.

Menurut Walgito mendefinisikan perilaku atau aktivitas kedalam pengertian yang luas yaitu perilaku yang tampak (overt behavior) dan perilaku yang tidak tampak (innert behavior), demikian pula aktivitas tersebut disamping motoris juga termasuk aktivitas emosional dan kognitif. Chaplin memberikan pengertian perilaku dalam dua arti. Pertama perilaku dalam arti luas didefinisikan sebagai segala sesuatu yang dialami seseorang. Kedua, perilaku didefinisikan dalam arti sempit yaitu segala sesuatu yang mencakup reaksi yang dapat diamati. $^{9}$

Remaja mulai merokok dikatakan oleh Erikson berkaitan dengan adanya krisis aspek psikososial yang dialami pada masa perkembangannya yaitu masa ketika mereka sedang mencari jati dirinya. Upaya-upaya untuk menemukan jati diri tersebut, tidak semua dapat berjalan sesuai dengan harapan masyarakat. Beberapa remaja melakukan perilaku merokok sebagai cara kompensatoris. Menurut WHO, stres adalah reaksi atau respon tubuh terhadap tekanan mental atau beban kehidupan. Stres adalah suatu kejadian atau stimulus lingkungan yang menyebakan individu merasa tegang. Rice menyampaikan bahsa stres mengacu pada peristiwa yang diperkirakan membahayakan kesejahteraan fisik dan psikologis seseorang. Situasi ini disebut sebagai penyebab stres. ${ }^{9}$ Sebuah studi mengatakan kebiasaan hidup yang buruk, adanya stres, lebih menggunakan metode coping negative jika marah dan putus asa berhubungan positif dengan perilaku merokok. $^{10}$

\section{Self Reporting Questionnaire-}

20 (SRQ-20) adalah kuesioner yang dikembangkan oleh WHO untuk skrining gangguan psikiatri dan keperluan penelitian yang telah dilakukan di berbagai negara. SRQ banyak digunakan di negara-negara yang sedang berkembang dan tingkat pendidikan penduduknya masih rendah. Selain itu SRQ 
juga sangat cocok digunakan di negara yang penduduknya masih banyak yang berasal dari tingkat sosial ekonomi rendah. ${ }^{11}$ Ada 20 butir pertanyaan yang sudah berhasil digunakan di pelayanan kesehatan tingkat pertama dan community based dan bisa juga dikerjakan langsung oleh responden/ self-administered atau melalui wawancara/ interview- administered. SRQ-20 terdiri dari pertanyaan pertanyaan mengenai gejala yang lebih mengarah kepada neurosis.

Menurut WHO, remaja adalah penduduk dalam rentang umur 10-19 tahun, menurut Peraturan Mennteri Kesehatan RI Nomor 25 Tahun 2014, remaja adalah penduduk dalam rentang usia 10-18 tahun, dan menurut Badan Kependudukan dan Keluarga Berencana (BKKBN) rentang usia remaja adalah 10-24 tahun dan belum menikah. Jumlah kelompok umur 10-19 tahun di Indonesia menurut Sensus Penduduk 2010 sebanyak 43,5 juta atau sekitar $18 \%$ dari jumlah penduduk. Di dunia, diperkirakan kelompok remaja berjumlah 1,2 milyar atau $18 \%$ dari jumlah penduduk dunia. ${ }^{3}$

\section{METODE}

Untuk menjawab tujuan penelitian digunakan data Riskesdas 2013. Periode analisis penelitian pada bulan April-Mei 2016 di Fakultas Kesehatan Masyarakat, Universitas Indonesia dengan populasi studi adalah subsampel Riskesdas yang berusia 15-24 tahun sebanyak 118.218 remaja. Metode sampling yang digunakan dalam estimasi nasional yaitu penarikan sampel dua tahap berstrata dan subsampel dari estimasi propinsi. Tahap pertama, memilih 250 kabupaten/kota secara probability proportional to size with replacement (PPS WR). Tahap kedua, dari setiap kabupaten/kota terpilih, dilakukan pemilihan blok sensus secara systematic sampling dari daftar blok sensus sampel Riskesdas Modul MDG ${ }^{\text {ee }}$. Data diperoleh dari data set Riskesdas 2013 yang sudah dipublikasi oleh Balai Penelitian dan Pengembangan Kesehatan Kementrian Kesehatan RI tahun 2013. Instrumen yang digunakan dalam pengumpulan data Riskesdas 2013 adalah kuesioner Riskesdas 2013 individu dan rumah tangga. Self Reporting Questionnaire-20 (SRQ-20), terdiri dari 20 butir pertanyaan yang termasuk dalam kuesioner Riskesdas 2013. Seluruh butir pertanyaan berisi tentang gejala emosional seperti depresi, cemas, somatik, kognitif, dan penurunan energi.

Data dianalisis dengan perangkat lunak statistik. Data yang dipakai merupakan data sekunder dari Riskesdas 2013 dengan recoding, yaitu pengkategorian ulang data Riskesdas 2013 sesuai dengan definisi operasional. Analisis hasil berupa analisis deskriptif, bivariabel, dan stratifikasi. Penelitian ini telah disetujui oleh Komisi Etik Penelitian Departemen Epidemiologi, Fakultas Kesehatan Masyarakat Universitas Indonesia.

\section{HASIL}

Data set yang diterima dari Balitbangkes RI diolah dengan sebelumnya mengeksplorasi data dan mengecek apakah data tersebut terdapat missing. Setelah terbukti tidak terdapat missing, maka proses analisis dilanjutkan dengan menggunakan analisis data survei dalam perangkat lunak statistik. Sampling unit, strata, dan pembobotan diatur dalam survei set sesuai dengan teknik sampling Riskesdas 2013 dan selanjutnya dimulai analisis sesuai dengan tujuan penelitian.

\section{Analisis Deskriptif Hubungan Variabel Distres Emosional dengan Perilaku Merokok}

\section{Distres Emosional}

Pengukuran status distres dinilai dengan menggunakan kuesioner Riskesdas 2013 IND pertanyaan bagian F butir F01-F20 dengan cut off point 6. Pertanyaan yang diajukan digunakan untuk mengukur kondisi dalam satu bulan terakhir. Jika responden menjawab „ya dari pertanyaan yang diajukan maka diberikan skor 1, sedangkan menjawab ,tidak ${ }^{e e}$ dari pertanyaan yang diajukan maka diberikan skor 0 , sehingga memiliki rentang skoring 0-20. Presentasi tertinggi didapatkan bahwa responden lebih sering mengalami sakit kepala $(18,95 \%)$, sulit tidur $(10,73 \%)$, tidak nafsu makan $(8,5 \%)$, mudah lelah $(7,72 \%)$, dan merasa tegang, cemas, atau khawatir $(6,55 \%)$ (Lihat Tabel 1). Berikut adalah tabel distribusi skoring butir pertanyaan lebih dari sama dengan 6 dan kurang dari 6 
Tabel 1. Distribusi Skoring Butir Pertanyaan Distres Emosional

\begin{tabular}{lrr}
\hline \multicolumn{1}{c}{ Butir pertanyaan } & \multicolumn{2}{c}{ Status distress emosional } \\
& Ya ( $\geq \mathbf{6})$ & Tidak $(<\mathbf{6})$ \\
\hline Sering menderita sakit kepala & 79,16 & 16,12 \\
Merasa tegang, cemas, atau khawatir & 71,23 & 2,42 \\
Mudah lelah & 69,50 & 3,62 \\
Sulit tidur & 65,32 & 6,55 \\
Tidak nafsu makan & 59,51 & 5,45 \\
Mudah takut & 58,14 & 2,17 \\
Sulit untuk mengambil keputusan & 57,19 & 1,53 \\
Sulit berpikir jernih & 53,07 & 1,09 \\
Mengalami rasa tidak enak di perut & 52,18 & 2,20 \\
Tangan gemetar & 44,58 & 1,21 \\
Merasa lelah sepanjang waktu & 43,25 & 0,71 \\
Pencernaan terganggu & 42,65 & 1,63 \\
Merasa tidak bahagia & 40,78 & 0,52 \\
Menangis lebih sering & 38,04 & 0,59 \\
Merasa sulit menikmati kegiatan sehari-hari & 36,31 & 0,39 \\
Kehilangan minat pada berbagai hal & 34,04 & 0,37 \\
Pekerjaan sehari-hari terganggu & 30,15 & 0,24 \\
Merasa tidak berharga & 26,90 & 0,19 \\
Tidak mampu melakukan hal-hal yang bermanfaat dalam hidup & 26,05 & 0,18 \\
Mempunyai pikiran untuk mengakhiri hidup & 13,94 & 0,07 \\
\hline
\end{tabular}

Setelah diketahui distribusi butir pertanyaan, selanjutnya dilakukan skoring. Responden yang mengalami distres emosional yaitu skoring lebih dari sama dengan 6 sebesar $5,25 \%$. Semakin banyak skoring, maka presentasinya semakin menurun, akan tetapi terjadi peningkatan presentasi pada skoring 20 .

Tidak adanya gejala distres emosional terbanyak pada gejala depresi $(95,51 \%)$ sedangkan responden lebih sering mengalami gejala somatik dibandingkan gejala lainnya $(76,61 \%)$. Jika dilihat dari tiap gejala, semakin banyak responden mengalami gejala, maka semakin cenderung mengalami distres emosional (Lihat Tabel 2).

Umur 17-19 tahun lebih tinggi mengalami distres emosional. Laki-laki cenderung lebih tidak memiliki gejala distres emosional dan perempuan cenderung memiliki lebih banyak gejala distres emosional, akan tetapi pada gejala cemas, laki-laki dengan 1 gejala cemas lebih tinggi daripada perempuan. Distres emosional paling banyak terjadi pada pendidikan kepala rumah tangga yang tamat SD (5,29\%). Pada daerah perkotaan lebih banyak ditemukan gejala distres emosional dibandingkan pedesaan. Status sosial ekonomi kelompok menengah atas lebih cenderung mengalami distres emosional $(5,66 \%)$.
Keberadaan ART yang merokok di rumah membuat responden cenderung memiliki gejala distres emosional dibandingkan dengan tidak adanya ART yang merokok di rumah.

\section{Perilaku Merokok}

Responden tidak pernah sama sekali merokok dalam satu bulan terakhir $(69,89 \%)$ lebih tinggi dibandingkan dengan responden yang setiap hari merokok $(19,87 \%)$, responden yang merokok kadang-kadang (7,99\%), tidak merokok tapi sebelumnya pernah merokok kadang-kadang $(1,84 \%)$, dan tidak merokok tapi sebelumnya pernah merokok setiap hari $(0,41 \%)$.

Perilaku merokok dikategorikan menjadi dua, yaitu merokok jika responden menjawab ya setiap hari dan ya kadang-kadang, dan tidak merokok jika responden menjawab tidak, tapi sebelumnya pernah merokok setiap hari, tidak, tapi sebelumnya pernah merokok kadangkadang, dan tidak pernah sama sekali. Responden yang menjawab tidak, tapi sebelumnya pernah merokok setiap hari dan tidak, tapi sebelumnya pernah merokok kadangkadang dikategorikan sebagai tidak merokok karena pengukuran pada saat diambil sampel 
Tabel 2. Distribusi Gejala Distres dengan Distres Emosional dan Perilaku Merokok

\begin{tabular}{ccc}
\hline Gejala Distres & Distres Emosional $(\boldsymbol{\%})$ & $\begin{array}{c}\text { Perilaku Merokok } \\
(\boldsymbol{\%})\end{array}$ \\
\hline Tidak ada gejala somatic & 0,42 & 27,27 \\
1 gejala somatic & 6,91 & 30,79 \\
2 gejala somatic & 27,92 & 30,47 \\
3 gejala somatic & 61,97 & 23,89 \\
4 gejala somatic & 88,94 & 25,60 \\
\hline Tidak ada gejala cemas & 0,43 & 26,80 \\
1 gejala cemas & 14,14 & 38,20 \\
2 gejala cemas & 53,7 & 27,95 \\
3 gejala cemas & 84,09 & 25,11 \\
\hline Tidak ada gejala depresi & 0,95 & 27,60 \\
1 gejala depresi & 36,28 & 31,40 \\
2 gejala depresi & 72,61 & 30,18 \\
3 gejala depresi & 92,45 & 30,55 \\
4 gejala depresi & 99,68 & 38,95 \\
5 gejala depresi & 100,00 & 30,44 \\
6 gejala depresi & 100,00 & 25,12 \\
7 gejala depresi & 100,00 & 25,02 \\
\hline Tidak ada gejala kognitif & 1,28 & 27,55 \\
1 gejala kognitif & 38,56 & 32,27 \\
2 gejala kognitif & 75,48 & 31,71 \\
3 gejala kognitif & 97,51 & 31,51 \\
\hline gejala penurunan energy & 0,98 & 27,51 \\
\hline gejala penurunan energy & 31,27 & 31,03 \\
\hline gidak ada & 72,75 & 31,34 \\
\hline & 97,26 & \\
\hline
\end{tabular}

responden statusnya tidak merokok dan presentasinya kecil. Responden yang merokok sebesar $27,87 \%$.

Dilihat dari keseluruhan masingmasing butir pertanyaan kuesioner, responden yang mengalami keluhan gejala distres emosional pada butir pertanyaan lebih banyak pada berperilaku tidak merokok. Keseluruhan responden dengan atau tanpa gejala distres emosional lebih banyak pada berperilaku tidak merokok (Lihat Tabel 2). Perilaku merokok terjadi peningkatan pada variabel umur, semakin tua umur maka semakin besar untuk merokok. Akan tetapi jika dibandingkan dengan perilaku tidak merokok, perilaku merokok responden lebih sedikit dibandingkan responden yang tidak merokok. Laki-laki cenderung berperilaku merokok dibandingkan perempuan $(46,96 \%)$. Semakin tinggi pendidikan kepala rumah tangga maka cenderung menurun perilaku merokoknya. Responden yang berperilaku merokok lebih banyak pada daerah pedesaan (29,84\%). Semakin tinggi tingkat sosial ekonomi maka semakin menurun perilaku merokoknya. Status sosial ekonomi kelompok menengah atas lebih cenderung berperilaku merokok (5,66\%). Keberadaan ART yang merokok di rumah membuat responden cenderung berperilaku merokok dibandingkan dengan tidak adanya ART yang merokok di rumah.

\section{Analisis Pengaruh Distres Emosional terhadap Perilaku Merokok}

Analisis bivariabel menggunakan pengkategorian dari setiap variabel kovariat. Umur dibagi menjadi dua kategori yaitu 15-19 dan 20-24 tahun. Pendidikan kepala rumah tangga dibagi dua kategori berdasarkan referensi penelitian sebelumnya yaitu pendidikan rendah dan pendidikan tinggi.

Besar efek variabel kausal utama distres emosional dengan perilaku merokok sebesar 1,01 (95\% CI 0,94-1,07), artinya remaja yang merokok kemungkinan mengalami distres emosional tidak berbeda dengan remaja yang tidak merokok. Dari 20 butir pertanyaan keluhan distres emosional, dapat dilihat bahwa responden yang mengalami sulit tidur $(\mathrm{OR}=1,47 ; 95 \%$ CI 1,43-1,51), merasa tidak bahagia $(\mathrm{OR}=1,25 ; 95 \%$ CI $1,17-1,32)$, dan 
sulit berpikir jernih $(\mathrm{OR}=1,20 ; 95 \% \mathrm{CI}=1,13$ 1,26) lebih berpengaruh untuk berperilaku merokok dibandingkan dengan butir pertanyaan keluhan lainnya. Jika diamati berdasarkan gejala distres emosional dihubungkan dengan perilaku merokok, didapatkan bahwa keseluruhan gejala tidak berpengaruh terhadap perilaku merokok responden.

\section{Analisis Stratifikasi}

Variabel kovariat umur, tempat tinggal, pendidikan KRT, dan sosial ekonomi keluarga, tidak memodifikasi efek hubungan distres emosional dengan perilaku merokok. Variabel jenis kelamin terdapat beda efek distres emosional terhadap perilaku merokok meskipun perbedaannya tidak begitu kecil. Keberadaan ART yang merokok tidak dapat dianalisis karena terdapat sel yang kosong sehingga dihilangkan dari analisis data stratifikasi (Lihat Tabel 3).

Tabel 3. Pengaruh Distres Emosional terhadap Perilaku Merokok Berdasarkan Strata Variabel Umur, Jenis Kelamin, Pendidikan Kepala Rumah Tangga, Tempat Tinggal, dan ART yang Merokok

\begin{tabular}{|c|c|c|c|c|}
\hline \multirow[t]{2}{*}{ Variabel } & \multirow{2}{*}{ Distres } & \multicolumn{2}{|c|}{ Perilaku merokok } & \multirow{2}{*}{ OR $(95 \%$ CI $)$} \\
\hline & & $\mathbf{Y a}$ & Tidak & \\
\hline \multicolumn{5}{|l|}{ Umur } \\
\hline \multirow[t]{2}{*}{ 15-19 tahun } & Ya & 594 & 2.696 & $1,06(0,97-1,15)$ \\
\hline & Tidak & 12.860 & 62.005 & \\
\hline \multirow[t]{2}{*}{ 20-24 tahun } & Ya & 587 & 1.094 & $0,95(0,86-1,04)$ \\
\hline & Tidak & 13.889 & 24.493 & \\
\hline \multicolumn{5}{|l|}{ Jenis kelamin } \\
\hline \multirow[t]{2}{*}{ Laki-laki } & Ya & 1.146 & 870 & $1,82(1,67-1,98)$ \\
\hline & Tidak & 26.482 & 37.382 & \\
\hline \multirow[t]{2}{*}{ Perempuan } & $\mathrm{Ya}$ & 35 & 2.920 & $2,06(1,51-2,82)$ \\
\hline & Tidak & 267 & 49.116 & \\
\hline \multicolumn{5}{|l|}{ Tempat tinggal } \\
\hline \multirow[t]{2}{*}{ Perkotaan } & Ya & 616 & 2.052 & $1,06(0,97-1,16)$ \\
\hline & Tidak & 11.947 & 42.426 & \\
\hline \multirow[t]{2}{*}{ Pedesaan } & Ya & 565 & 1.738 & $0,97(0,88-1,06)$ \\
\hline & Tidak & 14.802 & 44.072 & \\
\hline \multicolumn{5}{|l|}{ Pendidikan KRT } \\
\hline \multirow[t]{2}{*}{ Rendah } & $\mathrm{Ya}$ & 959 & 2.764 & $0,95(0,88-1,02)$ \\
\hline & Tidak & 21.488 & 59.028 & \\
\hline \multirow[t]{2}{*}{ Tinggi } & Ya & 222 & 1.026 & $1,12(0,97-1,29)$ \\
\hline & Tidak & 5.261 & 27.470 & \\
\hline \multicolumn{5}{|l|}{ Sosial ekonomi } \\
\hline \multirow[t]{2}{*}{ Rendah } & Ya & 475 & 1.381 & $0,90(0,81-1,00)$ \\
\hline & Tidak & 10.950 & 28.639 & \\
\hline \multirow[t]{2}{*}{ Tinggi } & Ya & 706 & 2.409 & $1,07(0,98-1,16)$ \\
\hline & Tidak & 15.799 & 57.859 & \\
\hline \multicolumn{5}{|l|}{ ART yang merokok } \\
\hline \multirow[t]{2}{*}{ Ada } & $\mathrm{Ya}$ & 1.181 & 3.198 & $0,97(0,90-1,03)$ \\
\hline & Tidak & 26.749 & 70.050 & \\
\hline \multirow[t]{2}{*}{ Tidak ada } & Ya & - & 592 & - \\
\hline & Tidak & - & 16.448 & \\
\hline
\end{tabular}


Secara teori dan penelitian sebelumnya, variabel jenis kelamin dan sosial ekonomi keluarga merupakan confounder hubungan distres emosional dengan perilaku merokok. Odds merokok pada responden yang distress emosional pada perempuan 2 kali dibandingkan dengan Odds merokok pada responden yang distres emosional pada laki- laki (Lihat Tabel 3).

Hasil adjusted OR pengaruh distres emosional terhadap perilaku merokok adalah
1,82 (95\% CI 1,66-1,99), artinya remaja yang merokok mengalami distres emosional sebesar 1,82 kali dibandingkan dengan remaja yang tidak merokok setelah dikontrol oleh variabel umur, pendidikan kepala rumah tangga, tempat tinggal, dan sosial ekonomi.

Dikarenakan jenis kelamin memodifikasi efek distres emosional terhadap perilaku merokok, maka dilakukan analisis untuk melihat OR tiap stratum jenis kelamin sebelum dan setelah dikontrol.

\section{Tabel 4. Odds Ratio Distres Emosional terhadap Perilaku Merokok pada Strata Jenis Kelamin}

\begin{tabular}{lll}
\hline Strata & Crude OR & Adjusted OR \\
\hline Laki-laki & $1,85(95 \%$ CI 1,70-2,03) & $1,79(95 \%$ CI 1,63-1,97) \\
Perempuan & $2,20(95 \%$ CI 1,55-3,14) & 2,16 (95\% CI 1,52-3,09) \\
Total & $1,87(95 \%$ CI $1,72-2,05)$ & $1,82(95 \%$ CI $1,66-1,99)$ \\
\hline
\end{tabular}

Remaja merokok yang distress emosional pada perempuan $(\mathrm{OR}=2,20 ; 95 \% \mathrm{CI}$ $1,55-3,14)$ lebih tinggi dibandingkan remaja merokok yang distress emosional pada lakilaki (OR=1,85; 95\% CI 1,70-2,03). Remaja merokok yang distress emosional pada perempuan $(\mathrm{OR}=2,16 ; 95 \%$ CI 1,52-3,09) tetap lebih tinggi dibandingkan remaja merokok yang distress emosional pada laki-laki setelah dikontrol oleh variabel umur, pendidikan kepala rumah tangga, tempat tinggal, dan sosial ekonomi (OR=1,79; 95\% CI 1,63-1,97). Perbandingan OR pada kedua strata sebelum dan setelah dikontrol tidak jauh berbeda (Lihat Tabel 4).

\section{PEMBAHASAN}

Individu-individu dengan problem psikiatrik dan terkait kepribadian tertentu yang membuat mereka lebih sering mengalami distres personal lebih cenderung untuk merokok. Individu dengan masalah psikiatri seperti gangguan major depressive, berbagai macam gangguan kecemasan, schizophrenia, gangguan kepribadian antisosial, dan individu dengan kepribadian tertentu yang menyebabkan mereka lebih sering mengalami distres pribadi lebih mungkin untuk merokok. Contohnya, kepribadian neuroticism (kecenderungan umum untuk mengalami perasaan negatif dan stress) ternyata berhubungan dengan tingginya prevalensi perilaku merokok. Penelitian terhadap keluarga, saudara kembar, dan molekul genetik menunjukkan bahwa faktor genetik ikut memainkan peran yang cukup signifikan dalam perilaku merokok dan distres. Secara lebih spesifik dapat dijelaskan bahwa terdapat banyak gen yang berperan ganda, mempengaruhi seorang individu untuk merokok dan membuat seorang individu cenderung mengembangkan kepribadian dan gangguan psikiatri yang berhubungan dengan stress. $^{12}$

Hasil penelitian mengatakan bahwa distres emosional berpengaruh terhadap perilaku merokok setelah dikontrol dengan variabel umur, jenis kelamin, pendidikan kepala rumah tangga, tempat tinggal dan sosial ekonomi keluarga (OR 1,82 ; 95\% CI 1,661,99). Hal ini sesuai dengan penelitian Finkelstein et.al dan Booker menghasilkan temuan bahwa tingkat stres yang tinggi berakibat terhadap meningkatnya rIsiko untuk merokok. ${ }^{13}$ Booker et al. secara lebih rinci menemukan bahwa para remaja yang melaporkan tingkat stres tinggi juga melaporkan tingkat merokok yang tinggi, niat yang lebih besar untuk merokok pada tahun depan, dan keinginan yang lebih kuat untuk merokok di SMA dibandingkan mereka yang melaporkan tingkat stres rendah. ${ }^{14}$ Mereka berharap dapat menjadi lebih relaks dengan merokok sehingga bisa mengalihkan perhatiannya dari keadaan yang menyebabkan stres. $^{14}$

Finkelstein et.al menemukan bahwa kejadian penuh stres yang paling sering dihadapi para remaja adalah hal-hal yang 
berhubungan dengan sekolah (seperti keharusan belajar untuk menghadapi ujian, dan mendapat nilai buruk), teman sebaya (seperti berdebat dengan teman), dan hal-hal pribadi (seperti gangguan tidur, keharusan bangun lebih pagi, dan sakit). ${ }^{13}$ Di samping itu, masa remaja merupakan masa seorang individu menghadapi masalah untuk pertama kalinya seperti masalah berat badan, jerawat, menstruasi, perkembangan yang tertinggal, rangsangan seksual, tekanan sekolah, kebosanan, orang tua yang cerewet, tekanan dari teman sebaya, dan masalah uang. Masalah-masalah tersebut menyebabkan remaja sangat rentan menghadapi stres.

Individu yang merokok banyak beranggapan bahwa rokok dapat membantunya merasa lega dan santai saat stres, padahal yang dirasakan itu merupakan bentuk ketergantungan terhadap nikotin ${ }^{15}$

Masalah emosional dan perilaku diantara perokok dan tidak perokok berbeda efeknya pada strata jenis kelamin. Hasil penelitian di Israel menyatakan bahwa remaja yang emosionalnya bermasalah meningkatkan risiko perilaku merokok dan remaja perempuan yang merokok memiliki masalah emosional yang lebih tinggi daripada laki-laki. Akan tetapi, tidak ada perbedaan risiko perilaku merokok yang signifikan pada remaja yang aktif dalam forum konseling di sekolah atau pelayanan kesehatan. $^{5}$ Perbedaan risiko strata jenis kelamin ini dapat diidentifikasi bahwa antara perempuan dan laki-laki memiliki coping stres yang berbeda sehingga berpengaruh pada penyaluran distres emosional.

Bias informasi memungkinkan terjadi karena pemakaian alat ukur status distres emosional yang tidak akurat. Penggunaan kuesioner yang dirancang untuk negara berkembang membuat pertanyaan yang mudah dimengerti responden tetapi jawabannya cenderung subjektif dan sulit diukur keakuratannya sehingga hasilnya kurang sensitif untuk menyimpulkan bahwa responden mengalami distres emosional. Selain itu, cut off point yang digunakan memungkinkan adanya misklasifikasi non-differensial yang arahnya mendekati null value.

Pemilihan blok sensus dengan mengeluarkan kriteria rumah tangga tidak biasa misalnya panti asuhan, barak militer, membuat remaja yang eligible tidak ikut terseleksi sebagai subjek penelitian. Proporsi laki-laki lebih banyak berperilaku merokok dibandingkan perempuan, akan tetapi odds ratio distres emosional terhadap perilaku merokok pada perempuan lebih tinggi daripada laki-laki. Hal ini menunjukkan bahwa adanya bias uncontrolled confounding. Terbatasnya pengambilan sampel pada rumah tangga tidak biasa membuat hasil penelitian tidak dapat digeneralisasikan pada populasi remaja di Indonesia, generalisasi terbatas pada remaja yang tinggal di rumah tangga.

\section{KESIMPULAN}

Variabel jenis kelamin memodifikasi efek hubungan distres emosional dengan perilaku merokok meskipun kecil nilainya. Hasil adjusted OR pengaruh distres emosional terhadap perilaku merokok pada strata jenis kelamin adalah 1,82 (95\% CI 1,66-1,99), artinya remaja yang merokok kemungkinan mengalami distres emosional sebesar 1,82 kali dibandingkan dengan remaja yang tidak merokok setelah dikontrol oleh variabel umur, pendidikan kepala rumah tangga, tempat tinggal, dan sosial ekonomi.

\section{DAFTAR PUSTAKA}

1. WHO. WHO report on the global tobacco epidemic, 2011. Geneva; 2011.

2. Asia WRO for S-E. Fact Sheet on Global Youth Tobacco Survey: Indonesia [Internet]. 2009. Tersedia pada:

http://www.searo.who.int/tobacco/data/ en/

3. WHO. Global Youth Tobacco Survey Indonesian Report. New Delhi; 2014.

4. N S, S S, TY A. Linking data to tobacco control program action among students aged 13-15 in Association of Southeast Asian Nations (ASEAN) member states, 2000-2006. Tob Control. 2008;17(6):372-8.

5. Schoval, Kleinfeld, Farbstein, Kanaaneh, Valevski, Apter, et al. Gender differences in emotional and Behavioral Disorder dan service use among adolescent smoker. J Eur Psychiatry. 2013;28:397-403.

6. RC K, P B, O D, Al E. Lifetime 
prevalence and age-ofonset distributions of DSM-IV disorders in the national comorbidity survey replication. Arch Gen Psychiatry. 2005;62:593-602.

7. Maes HH, Sullivan PF, Bulik CM, Neale MC, Prescott CA, Eaves LJ. A twin study of genetic and environmental influences on tobacco initiation, regular tobacco use and nicotine dependence. PsychologyMed. 2004;34(7):1251-61.

8. MJ G, M B. Ageing, sosial class, and common mental disorders: Longitudinal evidence from three cohorts in the West of Scotland. Psychol Med. 2011;41:5674.

9. Nasution, I.K. Perilaku Merokok pada Remaja. Medan: Universitas Sumatera Utara. 2007. Diakses pada 13 Februari 2016. Available from: http://repository.usu.ac.id/bitstream/123 456789/3642/1/132316815.pdf
10. Sheidow, A. J., Henry, D. B., Tolan, P. H., \& Strachan, M. K. (2014). The role of stress exposure and family functioning in internalizing outcomes of urban families. Journal of child and family studies, 23(8), 1351-1365.

11. WHO. A useres guide to the self reporting questionnaire. Geneva; 1994.

12. Davison, gerald C, John M. Neale \& Ann M. Kring 2006. Psikologi abnormal edisi 9.Jakarta : PT. Raja Grafindo Persada

13. Finkelstein DM, Kubzansky LD, Goodman E. Sosial Status, Stress, and Adolescent Smoking. J Adolesc Heal 39678-685. 2006;39:678-85.

14. Booker CL, Gallaher P, Unger JB, RittOlson A, Johnson CA. Stressful Life Events, Smoking Behavior, and Intentions to Smoke among a Multiethnic Sample of Sixth Graders. Ethn Health. 2004;9(4):369-97.

15. Komalasari D, Helmi AF. FaktorFaktor Penyebab Perilaku Merokok Pada Remaja. J Psikol. 2000;28:37-47. 